\title{
IN VITRO PHARMACOLOGICAL EFFECTS OF ASTRAGALUS EREMOPHILUS AND MELILOTUS PARVIFLORA
}

\author{
Muhammad Nadeem Khan, ${ }^{1}$ Muhstaq Ahmed, ${ }^{1}$ \\ MuHAMmad WaSim KhaN ${ }^{2}$ and Rahmat Ali Khan ${ }^{1 *}$ \\ ${ }^{1}$ Department of Biotechnology, University of Science and Technology Bannu-28100, KPK, Pakistan \\ 2Institute of Pharmacology, School of Pharmaceutical Sciences, Shandong University, Shandong, China
}

(Received: January 13, 2018; accepted: July 19, 2018)

Traditional medicines are composed of herbal formulations and their active ingredients and constituents which play a crucial role in the treatment of various human ailments. Astragalus eremophilus and Melilotus indicus (L.) All. (syn. Melilotus parviflora Desf.) are used traditionally as antiperspirant, tonic, diuretic, laxative and narcotic agents. The current study was designed to investigate the Astragalus eremophilus and Melilotus indicus (L.) All. (syn. Melilotus parviflora Desf.) methanol extracts for their antioxidant, antibacterial and antifungal activities. Fine powder of $A$. eremophilus and M. parviflora was extracted with $70 \%$ methanol to get crude methanol extract. Extract was characterized for antioxidant, antibacterial and antifungal activities. Antioxidant activity of various concentrations $(3 \mathrm{mg} / \mathrm{ml}, 1.5 \mathrm{mg} /$ $\mathrm{ml}, 0.75 \mathrm{mg} / \mathrm{ml}$, and $0.38 \mathrm{mg} / \mathrm{ml}$ ) of both plant extracts was analyzed using 2,2-Diphenyl-1-picrylhydrazyl (DPPH) free radical. Salmonella typhemorium, Klebsiella pneumoniae (gram-negative) and Staphylococcus aureus, Enterococcus faecalis (gram-positive) bacterial strains were used for assessment of antibacterial activities. Antifungal activities of $7.5 \mathrm{mg} / \mathrm{ml}, 5.0 \mathrm{mg} / \mathrm{ml}, 2.5 \mathrm{mg} / \mathrm{ml} \mathrm{(A.} \mathrm{eremophilus} \mathrm{and} \mathrm{M.} \mathrm{parviflora)}$ were conducted using Aspergillus niger, Aspergillus flavus, Aspergillus fumigatus and Candida albicons. At high concentration ( $3 \mathrm{mg} / \mathrm{ml})$, all the tested fractions of A. eremophilus and M. parvifora methanol extracts showed potent antioxidant activities, ranging between 83.8 and $63.33 \%$. Antibacterial activities revealed that $A$. eremophilus showed a maximum zone of inhibition (8.1 \pm 0.1$)$ on Salmonella typhenorium followed by Enterococcus faecalis (7.2 \pm 0.1$)$, Klebsellesa pneumonia $(6.1 \pm 0.6)$, and Staphylococcus aureus $(5.1 \pm 0.4)$, and at highest concentration $(7.5 \mathrm{mg} / \mathrm{ml})$, however, maximum zone of inhibition of Melilotus parviflora was at $7.5 \mathrm{mg} / \mathrm{ml}$ followed by $5.0 \mathrm{mg} / \mathrm{ml}$ and $2.5 \mathrm{mg} / \mathrm{ml}$ against Klebsiella pneumonia, Staphylococcus aureus, Salmonella typhemorium and Enterococcus faecalis. Antifungal assessment of both plant extracts showed that the higher concentration $(7.5 \mathrm{mg} / \mathrm{ml})$ has significant inhibitory effect as compared to control. The results can lead to the conclusion that A. eremophilus and M. parviflora methanol extracts are indeed sources of potential therapeutic compounds against antibacterial, antifungal and free radical associated disorders.

Keywords: Astragalus eremophilus - Melilotus parviflora - antioxidant - antibacterial - antifungal activity

*Corresponding author; e-mail address: Rahmatgul_81@yahoo.com, nadeem.ispar@gmail.com 


\section{INTRODUCTION}

Traditional herbal drugs are composed of herbs, herbal preparations, and finished herbal products, that contain active ingredients and bioactive metabolites [1,2], used worldwide for treatment of various human ailments $[5,18]$. In a great part of the developing countries $70-90 \%$ of the population depends on the herbal medications. Mostly in Africa $75 \%$ of the population relies upon herbal medication for primary health care $[20,33]$. WHO has assessed that $80 \%$ of the world's population depends on herbal remedies for maintaining their good health containing various bioactive compounds $[3,37]$. Medicinal plants have a powerful origin of both traditional and current medications [2]. Currently, pharmaceutical industries have invested a considerable measure of energy and financial sources in evolving natural constituents separated from plants [12]. The scientific tests on the antimicrobial activities of herbal constituents were first recorded in the late nineteenth century [13, 34]. Commercially proven numerous medications used as a part of current medications were first utilized in extract form herbal or traditional practices for different purposes that recommended conceivably valuable biological activity. The essential advantages of utilizing medicinal plant remedies are generally more secure than industrial manufactured drugs, these latter posing a significant and more inexpensive cure [27]. Plant extracts were used for the cure of various diseases and provide a base for every single traditional system $[22,23]$. Chemical constituents of medicinal plants like tannins, flavonoids, and phenolic compounds has important therapeutic significance $[9,18]$, and are utilized to cure different ailments [44]. Artemisene separated from Artemisia japonica is utilized as antiprotozoal in mammalians, and its alternative item referred to as artemitrene for control of malarial infections particularly Pf (Plasmodium falciparum) [19]. The spores of Guava herbal are accounted as an extensive number of organically dynamic constituents [17]. Different seeds like apricot seeds [46], mango kernels [28] and citrus pits [4] have a more noteworthy number of phenolic constituents.

The family Annonaceae is a group of blossoming plants which consist of bushes, floras or infrequently vines [35]. Bioactive constituents isolated from the family containing herbs revealed energizing natural attributes [14, 29], utilized as anthelmintic, bug spray and styptic [2]. Roots of different Astragalus species show are used to extremely old and surely well-known medications for the treatment of uterine carcinoma, leukemia, diabetes, nephritis, and as antiperspirant, tonic, and diuretic [10]. Melilotus indicus (L.) All. (syn. Melilotus parviflora Desf.) has been reported to be emollient, astringent, strongly laxative and narcotic. It contains coumarin, which is reported to be anticoagulant [1]. The present study was therefore undertaken to investigate the antioxidant, antibacterial and antifungal activities of the crude extracts of both plants. 


\section{MATERIALS AND METHODS}

\section{Plant collection and extraction}

Plants of Melilotus parviflora and Astragalus eremophilus were collected from the nearby agricultural fields of village Kakki, Bannu division K.P.K Pakistan at the peak of maturity during April and May 2016. Plants were identified by Assistant Professor Dr. Faizan Ullah (Department of Botany, University of Science and Technology Bannu), and a voucher specimen (MP-1, AE-1) respectively was submitted in the Herbarium of the University for onward reference. After shade drying the plants samples were cut into small pieces and then ground into fine powder. Seventy g powder of each plant was soaked in $300 \mathrm{ml}$ of $70 \%$ methanol at room temperature for $72 \mathrm{hrs}$. Then the extracts were filtered and evaporated using rotary evaporator.

\section{Antibacterial activity}

Agar well diffusion method was used for assessment of antibacterial activities [24, 39]. Wells were prepared in the nutrient agar media and the plants extracts were introduced in these wells. After incubation, the diameter of the zones of inhibition around each well was measured and compared against the zone of inhibition of the known concentrations of the standard antibiotics.

\section{Preparation of inoculum}

Few colonies of the bacterial isolate were transferred into nutrient broth. Broth was then placed in incubator shaker at $37{ }^{\circ} \mathrm{C}$ until the visible turbidity was equal or greater than $0.5 \mathrm{McFarland}$ standard. It was used within $30 \mathrm{~min}$ of preparation.

\section{Stock solution preparation}

$7.5 \mathrm{mg}$ of methanol extracts of each plant were solved in $1 \mathrm{ml}$ of dimethyl sulfoxide (DMSO) according to standard protocol to obtain $7.5 \mathrm{mg} / \mathrm{ml}$ solution, which was further diluted into $5.0 \mathrm{mg} / \mathrm{ml}$, and $2.5 \mathrm{mg} / \mathrm{m}$ concentrations.

\section{Bacterial strains used}

During the assay 2 gram-negative (Salmonella typhemorium, Klebsiella pneumoniae) and 2 gram- positive (Staphylococcus aureus, Enterococcus faecalis) bacterial strains were used. All the bacterial strains were refreshed in a liquid broth for 12-16 hrs and 
diluted with saline solution to adjust its turbidity to McFarland $0.5 \%$ barium sulfate turbidity standard.

\section{Agar well diffusion method}

Agar well diffusion method is widely used to evaluate the antimicrobial activity of plants. In this method agar plate surface was inoculated by spreading the microbial inoculum over the entire agar surface. Holes with a diameter of 6 to $8 \mathrm{~mm}$ was punched aseptically with a sterile cork borer, where a volume $(20-100 \mu \mathrm{L})$ of each plant extract $(7.5 \mathrm{mg} / \mathrm{ml}, 5.0 \mathrm{mg} / \mathrm{ml}$, and $2.5 \mathrm{mg} / \mathrm{ml}$ in DMSO) were introduced into each labeled well. Then, agar plates were incubated at $37{ }^{\circ} \mathrm{C}$. Ceftriaxone $1 \mathrm{mg} / \mathrm{ml}$ was used as positive control. The diameter of the inhibition zone $(\mathrm{mm})$ was measured in triplicate.

\section{Antifungal activity}

The agar tube dilution assay was used for the determination of antifungal activities of the plants as previously described [11]. Inoculums were prepared using SDA media (Saburoud dextrose agar). Methanol extract of each plant was prepared from the stock of as $7.5 \mathrm{mg} / \mathrm{ml}, 5.0 \mathrm{mg} / \mathrm{ml}, 2.5 \mathrm{mg} / \mathrm{ml}$ in DMSO. Terbinafine an antifungal agent $(1 \mathrm{mg} / \mathrm{ml})$ was used as positive control and pure DMSO as a negative control. $6 \mathrm{ml}$ of SDA media was added to each labeled test tube along with $100 \mu$ of prepared plant extract. All the test tubes were kept at slant position and allowed to solidify at room temperature. Finally, an inoculum of four strains, A. niger, A. flavus, A. fumigatus and C. albicons, was added. Tubes with that negative and positive control i.e. pure DMSO and terbinafine $1 \mathrm{mg} / \mathrm{ml}$ were also inoculated and incubated for a week at $28{ }^{\circ} \mathrm{C}$ in triplicate. The $\%$ of inhibition was calculated as:

$$
\% \text { inhibition of fungal growth }=\frac{100-\text { linear growth in test sample in } \mathrm{mm}}{\text { linear growth in control in } \mathrm{mm}} \times 100 \text {. }
$$

\section{Antioxidant activity}

The antioxidant activity was carried out according to a standard protocol [5]. 2, 2-diphenyl-1-picrylahydrazyl (DPPH) was prepared by solving $3 \mathrm{mg}$ of DPPH in $50 \mathrm{ml}$ of methanol and was kept at $20^{\circ} \mathrm{C}$ till needed. The DPPH stock was further diluted with methanol in order to get the correct optical density/absorbance of $0.980 \pm 0.02$ at $517 \mathrm{~nm}$ on a spectrophotometer (Hitachi,s U-510 Tokyo Japan). A 0.8 $\mathrm{ml}(800 \mu \mathrm{l})$ of DPPH solution and $0.2 \mathrm{ml}(200 \mu \mathrm{l})$ of methanolic extracts of each plant $(3 \mathrm{mg} / \mathrm{ml}, 1.5 \mathrm{mg} / \mathrm{ml}, 0.75 \mathrm{mg} / \mathrm{ml}$, and $0.38 \mathrm{mg} / \mathrm{ml}$ ) were mixed. The tubes were placed in dark for $15 \mathrm{~min}$ at room temperature. After the absorbance optical density 
was measured at $517 \mathrm{~nm}$. The \% scavenging activity measured sing the subsequent formula:

$$
\text { Scavenging } \%=\frac{\text { control absorbance }- \text { sample absorbance }}{\text { control absorbance }} \times 100 \text {. }
$$

The ascorbic acid was kept as positive control.

\section{RESULTS}

\section{Antibacterial effects of Melilotus parviflora and Astragalus eremophilus}

Various concentrations of Melilotus parviflora and Astragalus eremophilus methanol extracts were used for the investigation of their antibacterial activity against 4 different bacterial strains viz; Klebsiella pneumonia, Salmonella typhemorium, Enterococcus faecalis and Staphylococcus aureus using agar well diffusion method. Figure 1 reveals the effects of Astragalus eremophilus and Melilotus parviflora on Klebsiella pneumonia, Salmonella typhemorium, Staphylococcus aureus and Enterococcus faecalis. Astragalus eremophilus showed maximum zone of inhibition $(8.1 \pm 0.1)$ on Salmonella typhenorium followed by Enterococcus faecalis $(7.2 \pm 0.1)$, Klebsellesa pneumonia $(6.1 \pm 0.6)$, and Staphylococcus aureus $(5.1 \pm 0.4)$ and at highest concen-

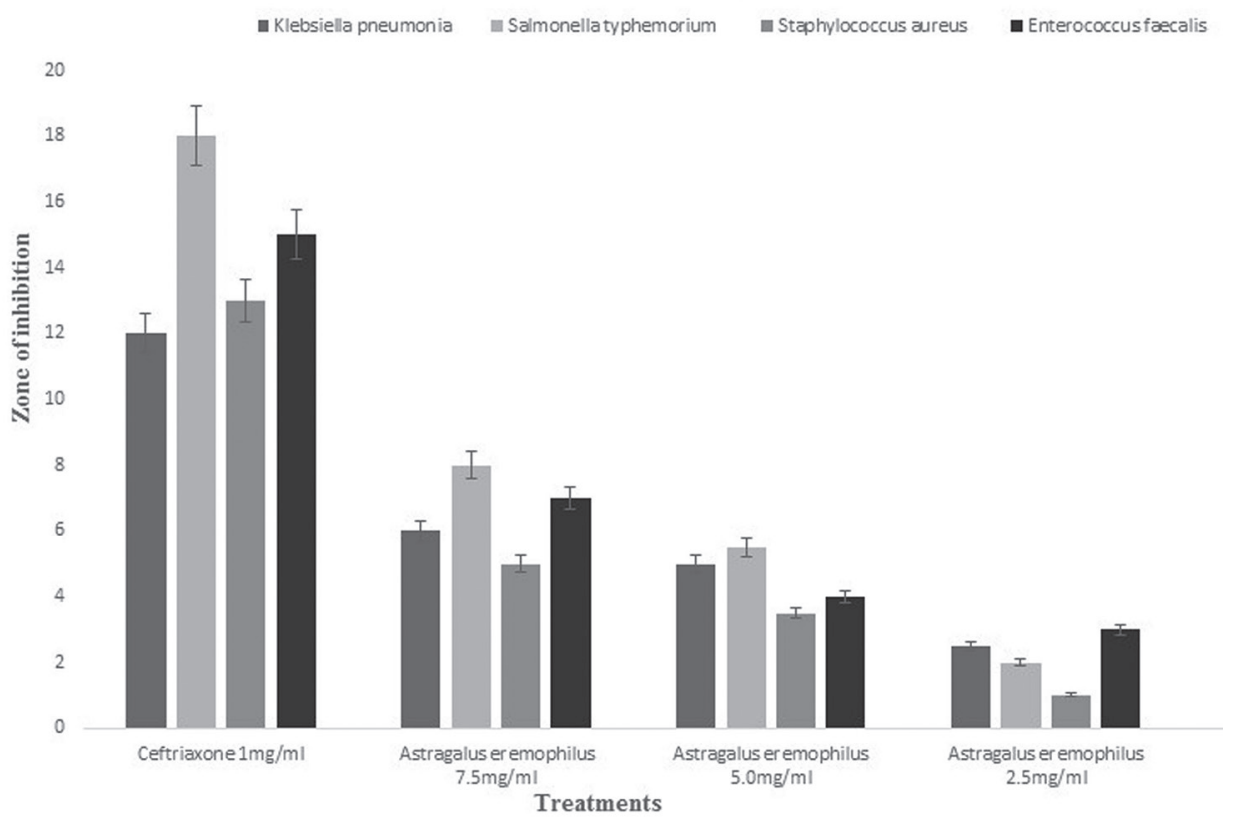

Fig. 1. Antibacterial activity of Astragalus eremophilus 


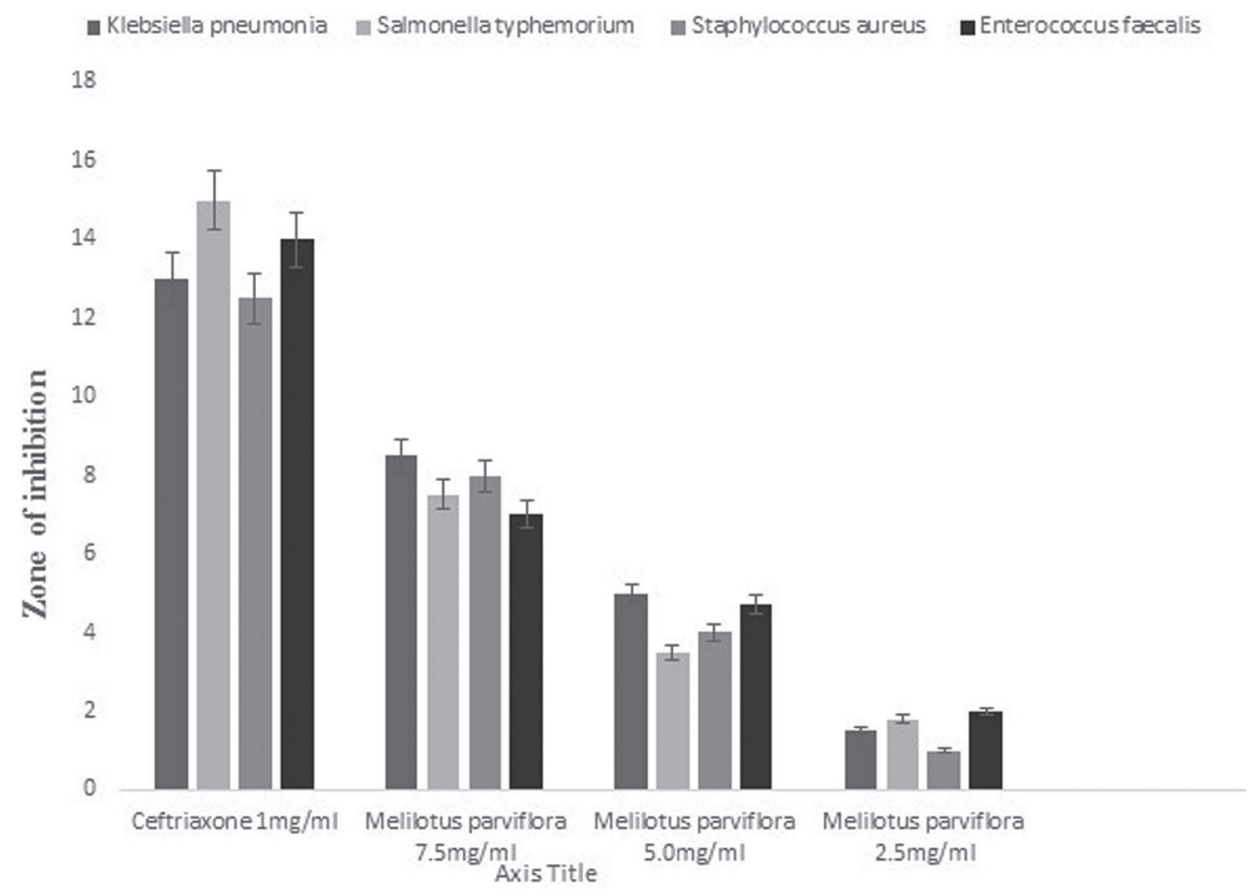

Fig. 2. Antibacterial activity of Melilotus parviflora

tration $(7.5 \mathrm{mg} / \mathrm{ml})$ while Melilotus parviflora showed the maximum zone of inhibition at $7.5 \mathrm{mg} / \mathrm{ml}$ followed by $5.0 \mathrm{mg} / \mathrm{ml}$ and $2.5 \mathrm{mg} / \mathrm{ml}$ against Klebsiella pneumonia, Staphylococcus aureus, Salmonella typhemorium and Enterococcus faecalis (Fig. 2). Positive control i.e. Ceftriaxone ( $1 \mathrm{mg} / \mathrm{ml})$ demonstrated considerable effects as compare all the tested plant extract samples and negative control (DMSO).

\section{Antifungal investigation of Melilotus parviflora and Astragalus eremophilus}

Fungi causes various human diseases. Antifungal agents obtained from medicinal plants play a crucial role in the control of fungal diseases. In the current study the antifungal effects of Melilotus parviflora and Astragalus eremophilus against four strains of fungi viz; Aspergillus flaveus, Aspergillus niger, Aspergillus fumigatus and Candida albicans were tested. Fig. 3 shows that Astragalus eremophilus has maximum inhibitory potential against Candida albicans (74.2\%) followed by Aspergillus flavus (63.1\%), Aspergillus fumigatus (61.3\%) and Aspergillus niger (57.1\%) at 7.5 $\mathrm{mg} / \mathrm{ml}$ however high concentration of Melilotus parviflora is more potent as compare to Astragalus eremophilus. Methanolic extract showed potent activity against 
Candida albicans (77.1\%), followed by Aspergillus fumigatus (70.1\%), Aspergillus flavus (67.5\%), and Aspergillus niger (64.0\%) respectively (Fig. 4).

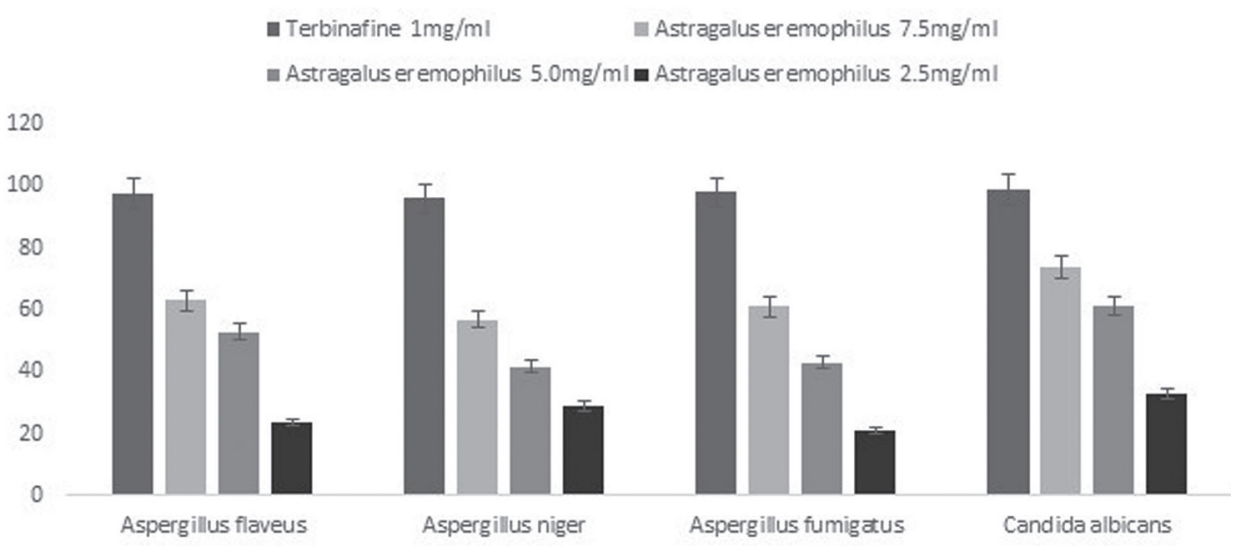

Fig. 3. Antifungal activity of Astragalus eremophilus

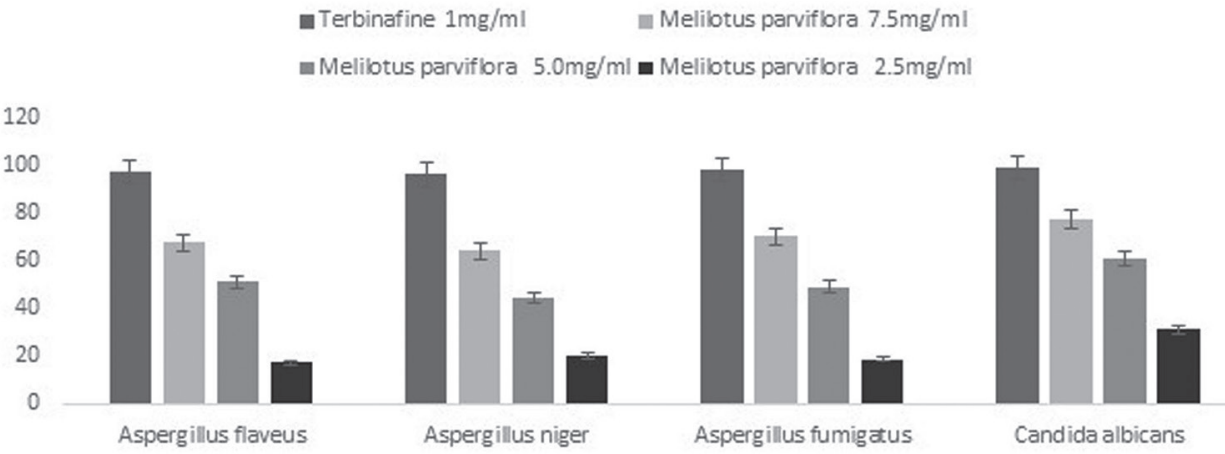

Fig. 4. Antifungal activity of Melilotus parviflora

\section{Antioxidant activity of Melilotus parviflora and Astragalus eremophilus}

2,2-Diphenyl-1-Picrylhydrazyl (DPPH) is a free radical and could attract electrons from antioxidant. The free radicals scavenging property of the methanol crude extract of Astragalus eremophilus, and Melilotus parviflora. The results revealed a direct relationship between the concentration of methanol extract and the \% scavenging of Astragalus eremophilus and Melilotus parviflora. Various concentrations of $3 \mathrm{mg} / \mathrm{ml}$, $1.5 \mathrm{mg} / \mathrm{ml}, 0.75 \mathrm{mg} / \mathrm{ml}$ and $0.38 \mathrm{mg} / \mathrm{ml}$ the free radical scavenging activity of Astragalus eremophilus is $83.8 \%, 72.89,69.67 \%$ and 33.73 ely. The order of $\%$ of free radicals scavenging activity is $3 \mathrm{mg} / \mathrm{ml}>1.5 \mathrm{mg} / \mathrm{ml}>0.75 \mathrm{mg} / \mathrm{ml}$ and $0.38 \mathrm{mg} /$ 
- Extract $\quad$ Asca bic acid

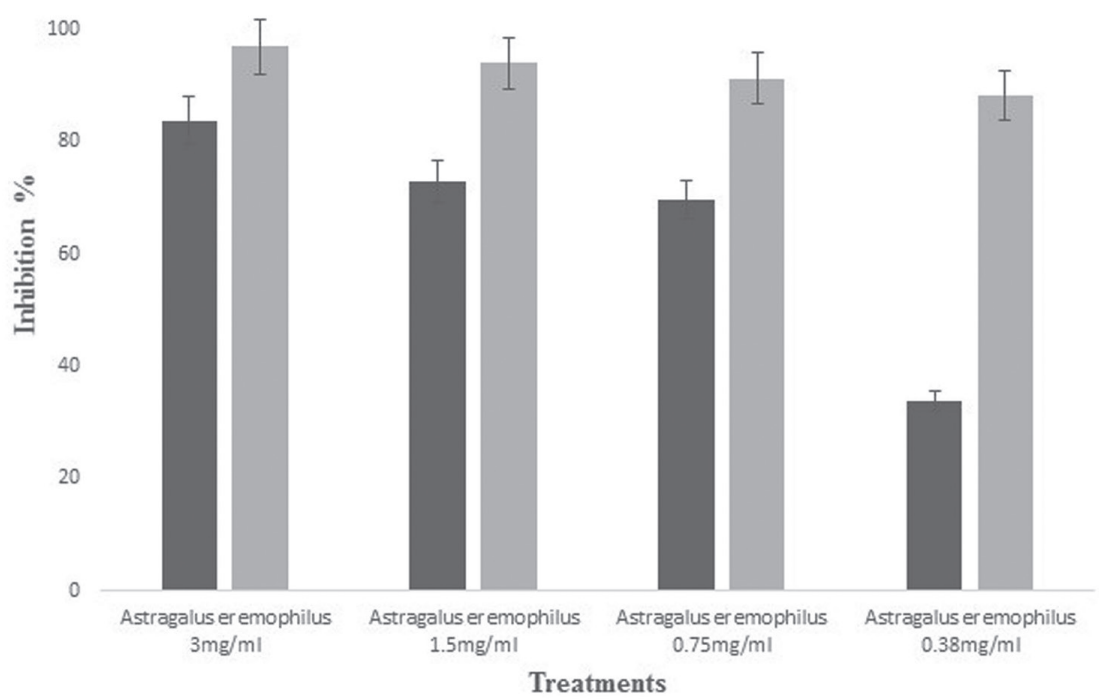

Fig. 5. Antioxidant activity of Astragalus eremophilus

120

Extract $\quad$ Ascarbic acid

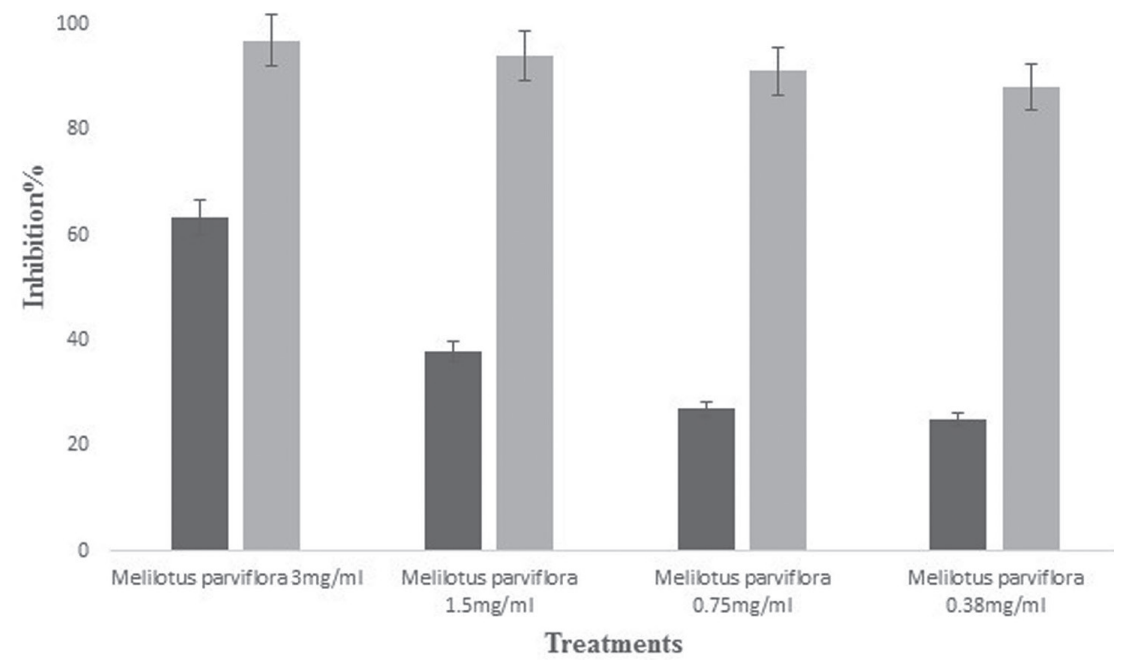

Fig. 6. Antioxidant activity of Melilotus parviflora 
$\mathrm{ml}$ (Fig. 5). Figure 6 shows that various concentrations of methanolic extract of Melilotus parviflora $(3 \mathrm{mg} / \mathrm{ml}, 1.5 \mathrm{mg} / \mathrm{ml}, 0.75 \mathrm{mg} / \mathrm{ml}$ and $0.38 \mathrm{mg} / \mathrm{ml}$ ) has concentration dependent effects $(63.33 \%, 37.75 \%, 26.97 \%$ and $24.96 \%)$ against scavenging of free radicals respectively. The present study reveals that Astragalus eremophilus methanol extract are the most effective as compared to Melilotus parviflora. The observed antioxidant activity of the Astragalus eremophilus and Melilitus parviflora methanolic extracts might be due to its high phenolic content.

\section{DISCUSSION}

Medicinal plants play a significant role in curing various oxidative damages including infections, diabetics, inflammation, heart disease, and cancer all over the world. Pakistan is rich in natural resources and medicinal floras which has been utilized by local communities for treatment of numerous ailments of skin, microbial and digestive disorders $[1,30]$. Oxidation is essential process for energy production, however during normal metabolism, through a number of enzymatic systems oxygen consumptions produces several reactive oxygen species such as hydrogen peroxide, superoxide radical and hydroxyl radical. In small amount these reactive oxygen species are useful in growth regulation and signal transduction. However large amount of reactive oxygen species produced oxidation stress, attacks protein and lipids molecules [21]. Data of the present study showed that extracts of both plants has marked radical scavenging potential at $3 \mathrm{mg} / \mathrm{ml}$ and $0.38 \mathrm{mg} / \mathrm{ml}$ concentrations. The antioxidant potential of the plants is due to the presence of bioactive polyphenolic and phenolic compounds which reduce the free radical that cause oxidative stress. The findings obtained by other reports also support our results $[16,25]$.

Medicinal plant extracts possess significant effects in the treatment of bacterial infections. In the current study four bacterial strains were selected to evaluate the antibacterial activity of each plant derived fractions. Our results showed that extracts obtained from Melilotus parviflora and Astragalus eremophilus display marked inhibitions against all gram positive and gram-negative bacteria. These significant inhibitions against all tested strains may be due to their phytoconstituents such as phenolics, tannins, saponins and flavonoids which are recommended for further studies. Several studies indicated that antimicrobial manifestations of plant extracts are due to their phenolics and contents [6,31]. Another investigation was reported that catechins were more efficient against gram positive bacteria than gram negative bacteria $[7,26]$. Literature revealed similar finding by other studies $[8,37,40]$.

Fungal causes various disease in living organism especially in human. To overcome their toxic effects various types of antifungal products are available in the market but all these have some side effects. Therefore, presently scientists are trying to develop such type of therapies which are friendly to living cell $[39,40]$. As a result of their considerations and discoveries they came to an end and prepared natural product for their control obtained from various natural sources especially from 
medicinal plants. In the present project it was demonstrated that Melilotus parviflora extracts exhibited maximum antifungal activity. The activity of C. albicans, A. fumigatus, A. flavus and A. niger was inhibited by a percentage value of $77.2 \pm 1.33 \%$, $70.1 \pm 1.12 \%, 67.5 \pm 1.11 \%$ and $64.3 \pm 1.37 \%$, respectively. Similar results were reported the in the course of characterization of the antimicrobial activity of other plants by other scientists $[8,36,46]$.

\section{REFERENCES}

1. Adeniji, I. T., Adio, A. F., Iroko, O. A., Kareem, A. A., Jegede, O. C., Kazeem-Ibrahim, F., Adewole, T. O., Adeosu, A. O. (2014) Pre-treatment of seeds of Annona squamosa (sugar apple) a non-timber forest product. Res. Plant Sci. 2, 50-52.

2. Akinyemi, K. O., Oladapo, O., Okwara, C. E., Ibe, C. C., Fasure, K. A. (2005) Screening of crude extracts of six medicinal plants used in South-West Nigerian unorthodox medicine for anti-methicillin resistant Staphylococcus aureus activity. BMC Compl. Alter. Med. 5, 6-13.

3. Bruneton, J. (1995) Pharmacognosy, phytochemistry, medicinal plants. Paris, Lavoisier Publishing.

4. Bocco, A., Marie, E. C., Hubert, R., Claudette, B. (1998) Antioxidant Activity and Phenolic Composition of Citrus Peel and Seed Extracts. J. Agric. Food Chem. 46, 2123-2129.

5. Brand-Williams, W., Cuvelier, M. E., Berset, C. (1995) Use of free radical method to evaluate antioxidant activity. Lebensm Wiss Technol. 28, 25-30.

6. Baba, A., Malik, S. A., Baba, A. S. (2015) Determination of total phenolic and flavonoid content, anti-microbial and antioxidant activity of a root extract of Arisaema jacquemonti Blume. J. Taib. Univ. Sci. 9, 449-454.

7. Burt, S. (2004) Essential oils, their antibacterial properties and potential applications in foods a review. Int. J. Food. Micro. 94, 223-253.

8. Bylka, W., Goslinska, O. (2001) Determination of isocytisoside andantimicrobial activity of ethanolic extract from Aquilegia vulgaris. J. Acta. Polo. Pharm. 58, 241-243.

9. Chhetri, H. P., Yogol, N. S., Sherchan, J., Mansoor, K. C. A., Thapa, P. S. (2008) Phytochemical and antimicrobial evaluations of some medicinal plants of Nepal. Kathmandu University J. Sci. Eng. Tech. $1,49-54$.

10. Chaudhary, L. B., Rana, T. S., Anand, K. K. (2008) Current status of the systematics of Astragalus L. (Fabaceae) with special reference to the Himalayan species in India. Taiwania 53, 338-355.

11. Choudhary, M. I., Dur-e-Shahwar, Z., Perveen, A., Atta-ur-Rahman, Ali, I. (1995) Antifungal steroidal lactones from Withania coagulance. Phytochemistry 40, 1243-1246.

12. Doughari, J. H. (2006) Antimicrobial activity of Tamarindus indica Linn. Trop. J. Pharm. Res. 5, 597-603.

13. De, M., De, A. K., Banerjee, A. B. (1999) Antimicrobial screening of some Indian spices. Phytother. Res. 13, 616-618.

14. De Quan, Y. U. (1999) Recent works on anti-tumor constituent from Annonaceae plants in China. Pure Appl. Chem. 71, 1119-1122.

15. De Luca, V., (2011) Monoterpenoid indole alkaloid biosynthesis. In: Ashihara, H., Crozier, A., Komamine, A. (eds), Plant Metabolism and Biotechnology. John Wiley and Sons Ltd., Chichester, pp. 263-291.

16. Duenas, M., Hernandez, T. Estrella, I. (2006) Assessment of in vitro antioxidant capacity of the seed coat and the cotyledon of legumes in relation to their phenolic contents. Food Chem. 98, 95-103.

17. Fellenberg, M. A., Espinoza, A., Peña, I., Alarcón, J. (2011) Antioxidant and Bacteriostatic Effects of the Addition of Extract of Quillay Polyphenols (Quillaja saponaria) in the Marinade of Broiler Chicken. Brazilian J. Poultry Sci. 1, 9-11. 
18. Ganapaty, S., Steve, T. P., Venkata, R. K., Neeharika, V. (2001) A review of phytochemical studies of Rauwolfia species. Indian Drugs 38, 601-612.

19. Holtz, C. (2007) Global health care: Issues and policies. Jones \& Bartlett Publishers, Sudbury, MA.

20. Hyat, M. Q., Khan, M. A., Ashraf, M., Jabeen, S. (2009) Ethnobotany of the Genus Artemisia L. (Asteraceae) in Pakistan. Ethnobot. Res. Appl. 7, 147-162.

21. Imperato, P. J. (1981) Modern and Traditional Medicine: The Case of Mali. Annals Intl. Med. 95, $650-651$.

22. Izzotti, A., Sacca, S. C., Longobardi, M., Cartiglia, C. (2010) Mitochondrial damage in the trabecular meshwork of patients with glaucoma. Arch. Ophthalmol. 128, 724-730.

23. Kalimuthu, K., Vijayakumar, S., Senthilkumar, R. (2010) Antimicrobial Activity of the Biodiesel Plant, Jatropha Curcas L. Intl. J. Pharma. Biosci. 1, 1-5.

24. Khan, A. M., Qureshi, A. M., Gillani, S. A., Ullah, F. (2011) Antimicrobial activity of selected medicinal plants of Margalla Hills, Islamabad Pakistan. J. Med. Plants Res. 5, 4665-4670.

25. Kavanagh, F. (1963) Analytical microbiology. Academic Press London.

26. Kilani, S., Sghaier, M. B., Limem, I., Bouhlel, I., Boubaker, J., Bhouri, W., Skandrani, I., Neffatti, A., Ammarb, R. A., Dijoux-Franca, R. A., Ghediram, K., Chekir-Ghedira, L. (2008) In vitro evaluation of antibacterial, antioxidant, cytotoxic and apoptotic activities of the tubers in fusion and extracts of Cyperus rotundus. Bioresource Technol. 99, 9004-9008.

27. Kabuki, T., Nakajima, H., Arai, M. (2000) Characterization of novel antimicrobial compounds from mango (Mangifera indica L.) Kernel Seeds. Food Chem. 71, 61-66.

28. Marjorie, M. C. (1999) Plant products as antimicrobial agents. Clinical Microbiol. Rev. 12, 564-582.

29. Maisuthisakul, P. (2008) Antiradical scavenging activity and polyphenolic compounds extracted from Thai mango seed kernels. Asian J. Food Agric. Ind. 1, 87-96.

30. Moerman, D. (1998) Native American ethnobotany Timber Press. Oregon.

31. Magaldi, S., Mata-Essayag, S., Hartung, C. (2004) Well diffusion for antifungal susceptibility testing. Intl J. Infec. Dis. 8, 39-45.

32. Mohanta, T. K., Patra, J. K., Rath, S. K., Pal, D. K., Thatoi, H. N. (2007) Evaluation of antimicrobial activity and phytochemical screening of oils and nuts of Semicarpus anacardium L.f. Sci. Res. Essay 2, 486-490.

33. Nadkarni's, K. M. (1976) Indian Materia Medica, Volume 1, Popular Prakashan, Mumbai.

34. Patwardhan, B., Hooper, M. (1992) Ayurveda and future drug development. Intl J. Alter. Compl. Med. 10, 9-11.

35. Robbers, J., Speedie, M., Tyler, V. (1996) Pharmacognosy and pharmacobiotechnology. Williams and Wilkins, Baltimore.

36. Sucher, N. J., Carles, M. C. (2008) Genome-Based Approaches to the Authentication of Medicinal Plants. Planta Medica 74, 603-623.

37. Slik, I. W. F., Poulsen, A. D., Ashton, P. S., Cannon, C. H., Eichhorn, K. A. O., Kartawinata, K., Lanniari, I., Nagamasu, H., Nakagawa, M., Van Nieuwstadt, M. G. L., Payne, J. (2003) A floristic analysis of the lowland dipterocarp forests of Borneo. Pak. J. Biol. Sci. 9, 2600-2605.

38. Stepanovic, S., Cirkovic, I., Mijac, V., Svabic-Vlahovic, M. (2003) Influence of the incubation temperature, atmosphere and dynamic conditions on biofilm formation by Salmonella spp. Food Microbiol. 20, 339-343.

39. Tewari, D. N. (2000) Report of the taskforce on conservation and sustainable use of medicinal plants Planning commission. 1-18.

40. Valgas, C., De Souza, S. M., Smânia, E. F. A. (2007) Screening methods to determine antibacterial activity of natural products. Brazilian J. Microbiol. 38, 369-380.

41. Villa F., Pitts B., Stewart P. S., Giussani B., Roncoroni S., Albanese D. (2011) Efficacy of zosteric acid sodium salt on the yeast biofilm model Candida albicans. Microbiol. Ecol. 62, 584-598.

42. WHO. Traditional medicine strategy 2003-2005. Geneva, World Health Organization, 2003. (WHO/ $\mathrm{EDM} / \mathrm{TRM} / 2003.1)$. 
43. World Health Organization (WHO). (1978) The promotion and development of traditional medicine, Technical report series pp. 622

44. Xu, L., Sun, N., Kong, J. (1992) Alkaloids of Annona reticulata L. Zhonqquo Zhong Yao Zazhi 17, 295-296.

45. Yang, X., Yang, L., Zheng, H. (2010) Hypolipidemic and antioxidant effects of mulberry (Morus alba L.) fruit in hyperlipidemia rats. Food Chem. Toxicol. 48, 2374-2379.

46. Yiğit, D., Yiğit, N., Mavi, A. (2009) Antioxidant and antimicrobial activities of bitter and sweet apricot (Prunus armeniaca L.) kernels. Brazilian J. Med. Biol. Res. 42, 346-352. 